\title{
Clinical aspects of sclerodermatous type graft-versus- host disease after allogeneic hematopoietic cell transplantation
}

\author{
Allogeneik hematopoietik hücre nakli sonrası sklerodermatoz tip graft-versus- \\ host hastalığının klinik yönleri
}

\author{
Hatice Şanlı1, Bengü Nisa Akay¹, Ender Soydan², Pelin Koçyiğit¹, Mutlu Arat², Osman IIlhan² \\ 1 University of Ankara School of Medicine Department of Dermatology, Ankara, Turkey \\ 2University of Ankara School of Medicine Department of Hematology, Ankara, Turkey
}

\begin{abstract}
Objective: We aimed to evaluate the clinical features of sclerodermatous chronic graft-versus-host disease (GVHD) after allogeneic hematopoietic stem cell transplantation (AHSCT).

Materials and Methods: We retrospectively analyzed 423 patients who underwent AHSCT. We assessed age, sex, pretransplant diagnosis, conditioning regimen, GVHD prophylaxis, and occurrence of acute GVHD (aGVHD), chronic lichenoid and chronic systemic GVHD, and clinical properties of sclerodermatous GVHD.

Results: Sclerotic skin lesions developed in 22 patients after a mean of $752 \pm 647$ days (median 480). aGVHD appeared in 17 patients, with hepatic involvement in 2, gastrointestinal tract involvement in 2 and skin involvement in 13 of these patients. Extensive chronic GVHD (liver, pulmonary, skin and oral mucosa) developed in 12 patients. Sclerosis was generalized in 19 patients (86.4\%) and localized in 3 patients (13.6\%). Leopard skin eruption appeared in 8 (36.4\%) of the 19 patients with generalized sclerodermatous changes. In most cases, sclerotic lesions appeared on the trunk, and distal parts of the extremities were spared. Eight patients (36.4\%) progressed from lichenoid to sclerodermatous lesions, 2 $(9.1 \%)$ with lichenoid and sclerodermatous phases together and 12 (55.5\%) with de novo sclerodermatous lesions. Five patients died because of late transplant-related complications.

Conclusion: Sclerodermatous GVHD has a late onset and may be quite disabling. Unlike scleroderma, acral involvement is seen rarely. Although most lesions do not disappear in the course of the disease, most patients have a good prognosis. (Turk J Hematol 2010; 27: 91-8)
\end{abstract}

Key words: Allogeneic hematopoietic stem cell transplantation, sclerodermatous graft-versus-host disease

Received: September 1, 2009

Accepted: April 27, 2010

\section{Özet}

Amaç: Allogeneik hematopoietik kök hücre nakli (Allo-HKHN) sonrası gelişen sklerodermatoz graft-versus-host hastalığının $(\mathrm{GVHH})$ klinik özelliklerinin değerlendirilmesi amaçlanmıştır.

Yöntem ve Gereçler: Allo-HKHN yapılan 423 hasta retrospektif olarak analiz edilmiştir. Olguların yaş, cinsiyet, transplantasyon öncesi taniları, hazırlık rejimleri, GVHH proflaksileri, akut GVHH ve/veya kronik likenoid ve kronik sistemik GVHH mevcudiyeti ve gelişen sklerodermatoz GVHH'nın klinik özellikleri değerlendirilmiştir.

Bulgular: Sklerotik lezyonlar 22 hastada ortalama 752 647 gün (ortanca 480) sonra gelişmiştir. Akut GVHH 17 hastada gelişirken, bunların 2'sinde karaciğer, 2'sinde gastrointestinal sistem ve 14'ünde deri tutulumu gözlenmiştir. Yaygın kronik GVHH (karaciğer, akciğer, deri ve oral mukoza) 12 hastada gelişmiştir. Skleroz 19 hastada (\%86.4) jeneralize, 3 hastada (\%13.6) lokalizeydi. Jeneralize sklerodermatoz değişiklikler izlenen 19 hastanın 8'inde (\%36.4) leopar derisi görünümü 
mevcuttu. Olguların çoğunda sklerotik lezyonlar gövdede yerleșirken, ekstremitelerin distali etkilenmemiştir. Olguların 8'i likenoid GVHH'dan sklerodermatoz GVHH'ye dönüşürken, 2'sinde her iki faz bir arada ve 12'sinde sklerodermatoz GVHH denovo olarak gelişmiştir. Beş olgu transplantasyonla ilişkili geç komplikasyonlar nedeniyle vefat etmiştir

Sonuç: Sklerodermatoz GVHH geç başlangıçlı ve hastalar için oldukça sıkıntı oluşturabilen bir tablodur. Sklerodermanın aksine akral tutulum nadiren görülür. Lezyonlar hastalık seyri boyunca kaybolmamakla birlikte pek çok olguda prognoz iyidir. (Turk J Hematol 2010; 27: 91-8)

Anahtar kelimeler: Allogeneik hematopoietik kök hücre nakli, Sklerodermatoz Graft-Versus-Host Hastalığı

\section{Introduction}

The development of acute and chronic graft-versus-host disease (aGVHD, cGVHD) after allogeneic hematopoietic stem cell transplantation (AHSCT) remains a major clinical problem associated with significant morbidity and mortality [1,2]. The skin, gastrointestinal tract and liver are the organs primarily affected [3].

Chronic GVHD (cGVHD) remains a major complication of AHSCT, and it affects more than 50\% of long-term survivors of AHSCT [4]. CGVHD can occur anytime from months to years after AHSCT and may or may not be preceded by episodes of aGVHD. Lichenoid and sclerodermatous changes have been described [2-6]. Sclerodermatous CGVHD is distinguished by plaques of dermal sclerosis resembling morphea, and eventually by generalized scleroderma, often resulting in joint contractures [1-3,5-7].

Nevertheless, few data are available regarding the late sclerodermatous phase of cGVHD. Most authors do not separate lichenoid and sclerodermatous CGVHD in their reports. In this study, we describe the clinical features of 22 patients with sclerodermatous cGVHD who had received AHSCT.

\section{Materials and Methods}

We retrospectively analyzed 423 patients who underwent AHSCT. The study was conducted by the Departments of Dermatology and Hematology in one of the largest university hospitals in Turkey. We reviewed the clinical characteristics after the appearance of sclerodermatous cGVHD. We assessed age, sex, pre-transplant diagnosis, conditioning regimen, GVHD prophylaxis, preceding aGVHD and/or lichenoid CGVHD, and clinical properties of sclerodermatous cGVHD. The patient data are summarized in Table 1. The diagnosis and grading of aGVHD and CGVHD were made according to the recent National Institutes of Health $(\mathrm{NIH})$ consensus conference [8]. Mild cGVHD involves only one or two organs or sites (except lungs, with no clinically significant impairment). Moderate cGVHD involves at least one organ or site with clinically significant impairment but no major disability, or three or more organs or sites with no clinically significant functional impairment. Severe cGVHD indicates major disability caused by cGVHD [8]. The skin lesions in cGVHD were classified as: (1) lichenoid lesions or (2) sclerodermatous lesions. Patients were classified as having generalized sclerodermatous CGVHD if more than two anatomic sites were involved and as localized in the remaining cases. The clinical diagnosis of CGVHD was established by a dermatologist and the diagnosis of cutaneous sclerodermatous GVHD was established based on both clinical and dermatopathological findings. Pigmentation changes like widespread, well-demarcated, hyperpigmented macules (leopard skin-like pigmentary changes) [2], areas of hypopigmentation, depigmentation, poikiloderma (atrophic and pigmentary changes), lichen sclerosus-like lesions (discrete to coalescent gray to white movable papules and plaques), keratosis pilaris, and ichthyosis were also evaluated. Presence of Raynaud phenomenon, sclerodactyly, and esophageal, joint and/or lung involvement was noted. Autoimmune markers such as anti-nuclear antibodies (ANA), anti-double-stranded DNA (anti-DsDNA), SCL70 and anti-centromere antibodies (ACA) were screened after the diagnosis of sclerodermatous GVHD.

Moderate or severe GVHD was treated with $3-5 \mathrm{mg} / \mathrm{kg} /$ day cyclosporine $(\mathrm{CsA})$ and $1 \mathrm{mg} / \mathrm{kg} /$ day prednisone in patients already receiving CsA therapy (Seattle regimen). In non-responders, $15 \mathrm{mg} / \mathrm{kg} /$ dose twice daily mycophenolate mofetil (MMF) and/or extracorporeal photopheresis (ECP) were added to CsA therapy. UVAR XTS system (Therakos, Exton, PA, USA) was used during ECP. Each cycle of ECP consisted of two consecutive days at two-week intervals for the first three months and thereafter every four weeks until a maximum period of one year. Psoralen-UV-A (PUVA) therapy was given using oral 8-methoxypsoralen and a UV-A dosimetry regimen. PUVA was delivered three times weekly starting at a dose of $0.5 \mathrm{~J} / \mathrm{cm}^{2}$ and increasing the dose by $0.5 \mathrm{~J} /$ $\mathrm{cm}^{2}$ increments at each treatment to a maximum dose of 6 $\mathrm{J} / \mathrm{cm}^{2}$. Patients were clinically examined twice weekly during the first three months and monthly afterwards. Response to therapy was defined as complete if less than $2 \%$ of the skin surface showed tightness and all other signs associated with cGVHD had disappeared [5]. Patients who did not show any improvement in the sclerotic changes were defined as nonresponsive. The response was defined as partial in the remaining cases.

A statistical analysis was performed using SPSS 15.0. Simple descriptive statistics were tabulated. The chi-square test and Fisher's exact probability test were used to analyze 
Table 1. Patient data

\begin{tabular}{|c|c|c|c|c|c|c|c|c|c|c|c|c|c|c|}
\hline Age & $\begin{array}{l}\text { Recipient } \\
\text { Sex }\end{array}$ & $\begin{array}{c}\text { Donor } \\
\text { Sex }\end{array}$ & Diagnosis & \multicolumn{2}{|c|}{$\begin{array}{l}\text { Sype of } \\
\text { Transplantation }\end{array}$} & \multirow{2}{*}{$\begin{array}{c}\begin{array}{c}\text { Conditioning } \\
\text { regimen }\end{array} \\
\mathrm{BU}+\mathrm{CY} \\
\end{array}$} & \multirow{2}{*}{$\begin{array}{l}\text { Prophylaxis } \\
\text { CSA+MTX }\end{array}$} & \multirow{2}{*}{$\begin{array}{c}\text { aGVHD } \\
+\end{array}$} & \multirow{2}{*}{$\begin{array}{r}\text { cGVHD } \\
\text { Moderate }\end{array}$} & $\begin{array}{c}\text { Skin } \\
\text { pattern }\end{array}$ & \multirow{2}{*}{$\begin{array}{c}\begin{array}{c}\text { Skin pigmentation } \\
\text { disorders }\end{array} \\
\text { Hyperpigmentation }\end{array}$} & \multirow{2}{*}{$\begin{array}{l}\text { Therapy } \\
\text { Prednisone }\end{array}$} & \multirow{2}{*}{$\begin{array}{c}\text { Survival } \\
\text { alive }\end{array}$} & \multirow{2}{*}{$\begin{array}{c}\text { Response } \\
\text { NR }\end{array}$} \\
\hline 42 & M & $\mathrm{F}$ & AML & AШO & $\mathrm{BM}$ & & & & & $G$ & & & & \\
\hline 21 & $\mathrm{~F}$ & M & $\mathrm{A} L$ & AแO & BM & CY-TBI & CSA+MTX & + & Mild & $G$ & $\begin{array}{c}\text { Hypo- } \\
\text { and } \\
\text { hyperpigmentation, } \\
\text { poikiloderma }\end{array}$ & $\begin{array}{l}\text { CsA } \\
\text { MMF }\end{array}$ & exitus & $\mathrm{NR}$ \\
\hline
\end{tabular}

\begin{tabular}{|c|c|c|c|c|c|c|c|c|c|c|c|c|c|c|}
\hline 20 & M & $\mathrm{F}$ & $\mathrm{CML}$ & ALLO & $\mathrm{BM}$ & $\mathrm{BU}+\mathrm{CY}$ & CSA+MTX & Absent & Mild & $\mathrm{L}$ & No & CsA & alive & NR \\
\hline 26 & M & $\mathrm{F}$ & CML & ALO & BM & $\mathrm{BU}+\mathrm{CY}$ & CSA+MTX & + & Mild & $\mathrm{L}$ & No & CsA & alive & $N R$ \\
\hline 42 & M & $\mathrm{F}$ & CML & ALLO & $\mathrm{BM}$ & $\mathrm{BU}+\mathrm{CY}$ & CSA+MTX & + & Mild & $G$ & Hyperpigmentation & CsA & alive & NR \\
\hline 30 & $M$ & $M$ & AML & ALLO & $\mathrm{BM}$ & $\mathrm{BU}+\mathrm{CY}$ & CSA+MTX & + & Mild & $\mathrm{L}$ & No & CsA & alive & NR \\
\hline 31 & M & $\mathrm{F}$ & AML & ALLO & PB & $\mathrm{BU}+\mathrm{CY}$ & CSA+MTX & + & Severe & G & $\begin{array}{c}\text { Hypo- } \\
\text { and } \\
\text { hyperpigmentation }\end{array}$ & $\begin{array}{c}\text { CsAt } \\
\text { prednisone }\end{array}$ & exitus & NR \\
\hline 40 & M & $\mathrm{F}$ & MDS & ALO & PB & $\mathrm{BU}+\mathrm{CY}$ & CSA+MTX & + & Severe & $G$ & Hyperpigmentation & $\mathrm{Cs} A+E C P$ & alive & NR \\
\hline 14 & M & M & $\mathrm{CML}$ & ALOO & PB & $\mathrm{BU}+\mathrm{CY}$ & CSA+MTX & Absent & Mild & G & $\begin{array}{c}\text { Hypo- } \\
\text { and } \\
\text { hyperpigmentation, } \\
\text { poikiloderma }\end{array}$ & CsA & exitus & NR \\
\hline 36 & $\mathrm{~F}$ & M & AML & ALO & PB & $\mathrm{BU}+\mathrm{CY}$ & CSA+MTX & + & Severe & $G$ & Hyperpigmentation & CsA+ECP & alive & NR \\
\hline 41 & $\mathrm{~F}$ & M & CML & ALLO & PB & $\begin{array}{c}\text { FLU-BU(iv)- } \\
\text { ATG }\end{array}$ & CSA+MMF & Absent & Mild & G & $\begin{array}{c}\text { Hypo- } \\
\text { and } \\
\text { hyperpigmentation }\end{array}$ & $\mathrm{MMF}+\mathrm{ECP}$ & alive & NR \\
\hline 43 & $\mathrm{~F}$ & $M$ & AML & ALLO & PB & $\mathrm{BU}+\mathrm{CY}$ & CSA+MTX & + & Severe & $G$ & $\begin{array}{c}\text { Hypo- } \\
\text { and } \\
\text { hyperpigmentation, } \\
\text { poikiloderma }\end{array}$ & $\begin{array}{c}\text { MMF- } \\
\text { CsA+ECP }\end{array}$ & alive & PR \\
\hline
\end{tabular}

\begin{tabular}{|c|c|c|c|c|c|c|c|c|c|c|c|c|c|c|}
\hline 30 & M & $\mathrm{F}$ & AML & AщO & PB & $\mathrm{BU}+\mathrm{CY}$ & CSA+MTX & + & Moderate & G & Hyperpigmentation & MMF & alive & NR \\
\hline 26 & $\mathrm{~F}$ & M & AML & АШO & PB & $\mathrm{BU}+\mathrm{CY}$ & CSA+MTX & + & Severe & $G$ & Hyperpigmentation & $\begin{array}{c}\text { MMF } \\
\text { CsA+ECP }\end{array}$ & alive & $\mathrm{PR}$ \\
\hline 41 & M & M & AML & АЦО & PB & $\mathrm{BU}+\mathrm{CY}$ & CSA+MTX & + & Moderate & $G$ & $\begin{array}{c}\text { Hypo- } \\
\text { and } \\
\text { hyperpigmentation }\end{array}$ & SA+ prednisone & ealive & NR \\
\hline 31 & $\mathrm{~F}$ & M & MM & АШO & PB & $\mathrm{FLU}+\mathrm{TBI}$ & CSA+MMF & + & Mild & $G$ & $\begin{array}{l}\text { Hypo- } \\
\text { and }\end{array}$ & ECP & alive & NR \\
\hline
\end{tabular}

hyperpigmentation

\begin{tabular}{|c|c|c|c|c|c|c|c|c|c|c|c|c|c|c|}
\hline 17 & M & $\mathrm{F}$ & MDS & AщO & PB & $\mathrm{BU}+\mathrm{CY}$ & CSA+MTX & + & Moderate & $G$ & Hyperpigmentation & $\begin{array}{l}\text { MMF } \\
\text { PUVA }\end{array}$ & alive & PR \\
\hline 41 & $\mathrm{~F}$ & $F$ & AML & АШО & PB & FLU+Mel & CSA+MMF & + & Mild & $\mathrm{G}$ & $\begin{array}{c}\text { Hypo- } \\
\text { and } \\
\text { hyperpigmentation, }\end{array}$ & CsA & exitus & NR \\
\hline
\end{tabular}

\begin{tabular}{|c|c|c|c|c|c|c|c|c|c|c|c|c|c|c|}
\hline 27 & M & $\mathrm{F}$ & CML & ALO & PB & $\mathrm{BU}+\mathrm{CY}$ & CSA+MTX & Absent & Severe & $G$ & Hyperpigmentation & ECP & alive & PR \\
\hline 42 & $\mathrm{~F}$ & $M$ & CML & AШO & PB & $\mathrm{FLU}+\mathrm{BU}$ & CSA+MMF & Absent & Moderate & $G$ & Hypo- & MMF & alive & $N R$ \\
\hline
\end{tabular}

hyperpigmentation

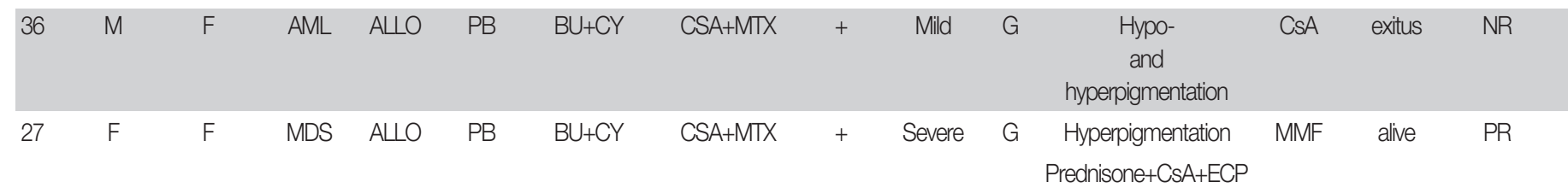

AL: Acute lymphoblastic leukemia; AML: Acute myeloblastic leukemia; CML: Chronic myelogenous leukemia; MDS: Myelodysplastic syndrome; Allo: Allogeneic; BM: Bone marrow; PB: Peripheral blood; BU: Busulphan; MTX: Methotrexate; CY: Cyclophosphamide; FLU: Fludarabine; ATG: Antithymocyte globulin; TBI: Total body irradiation; Mel: Melphalan; CSA: Cyclosporine; MMF: Mycophenolate mofetil; ECP: Extracorporeal photochemotherapy; PUVA: Psoralen-UV-A; G: Generalized; L: Localized; NR: Non-responder; PR: Partial response 
differences between groups. Values of $p<0.05$ were considered statistically significant.

\section{Results}

The development of sclerodermatous GVHD was observed in $22(5.2 \%)$ out of 423 patients. Thirteen patients were male and 9 were female, with a mean age of $32 \pm 9$ years. All the patients were transplanted from HLA-identical sibling donor. Sex mismatch was found to be statistically significant in the development of sclerodermatous GVHD ( $p=0.02)$. CsA plus short-term methotrexate $(n=18)$ or MMF $(n=4)$ was used for prophylaxis of GVHD (Table 1). History of aGVHD (> Grade II) was present in 17 patients (77\%), with hepatic involvement in 2, gastrointestinal tract involvement in 2 and skin involvement in 13 patients. Eight patients (36.4\%) progressed from lichenoid to sclerodermatous lesions, 2 (9.1\%) with lichenoid and

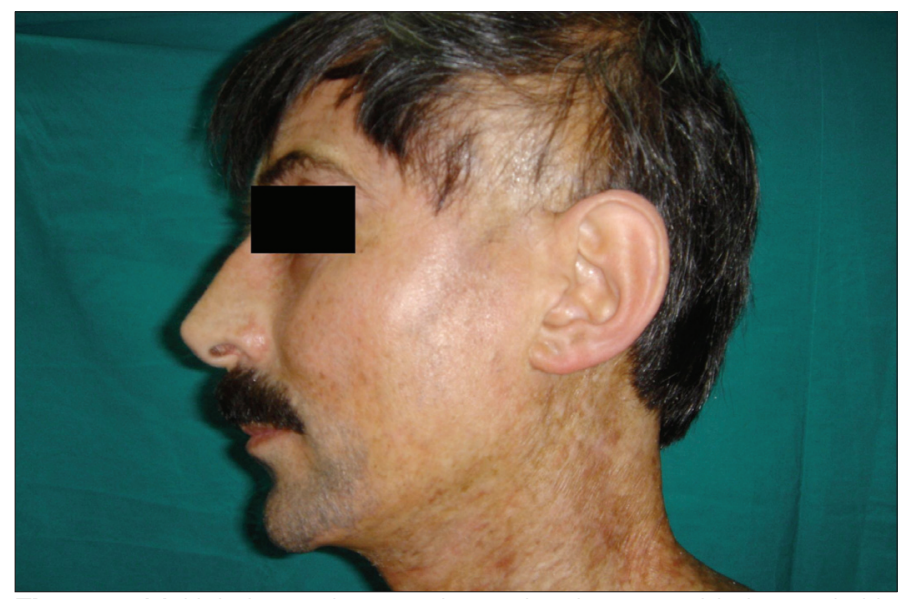

Figure 1. Multiple hyperpigmented macules that resemble leopard skin on the neck and cicatricial alopecia on the left temporal region

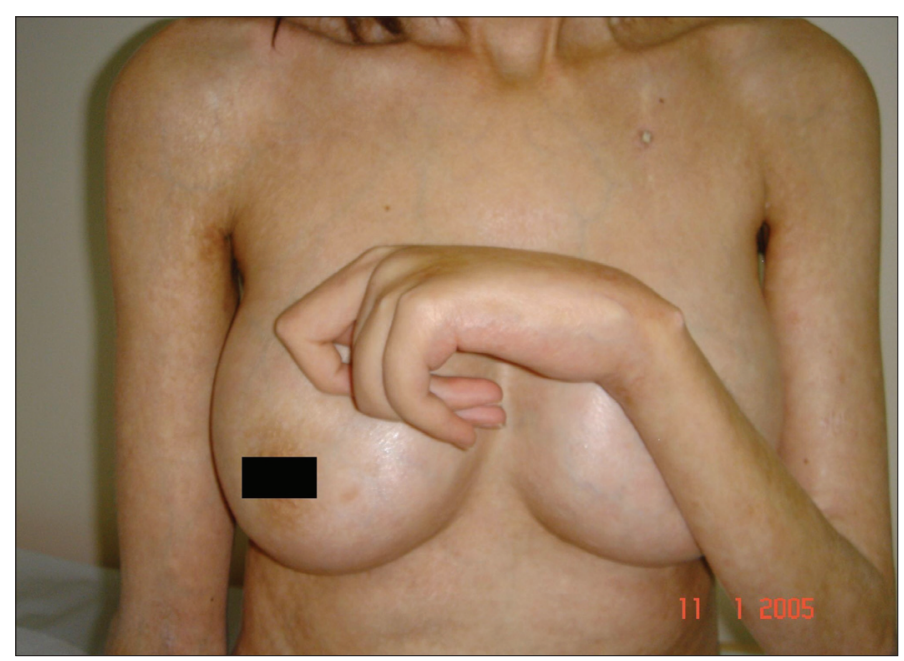

Figure 3. Sclerodermatous cGVHD causing severe contractures of the wrists and fingers sclerodermatous phases together and 12 (55.5\%) with de novo sclerodermatous lesions.

Clinical features of chronic sclerodermatous GVHD:

Moderate (7 patients) or severe (5 patients) cGVHD developed in 12 patients, while it was mild in 10 patients. Five patients (23\%) developed de novo chronic cutaneous GVHD without a previous aGVHD. Sclerotic lesions developed after a mean of $752 \pm 647$ days (median 480). Immunosuppressive therapy was interrupted in 16 (72\%) patients before sclerodermatous lesions had developed. Sclerosis was generalized in 19 patients (86.4\%) and localized in 3 patients (13.6\%). There was no statistically significant difference between the extensiveness of sclerodermatous GVHD and presence of previous aGVHD $(p=1.00)$ or cGVHD $(p=0.21)$. Widespread, welldemarcated, hyperpigmented macules and hypo-hyperpigmentation appeared in 8 (36.4\%) and 11 (50\%) patients, respectively (Figure 1). In most of the patients, sclerotic lesions

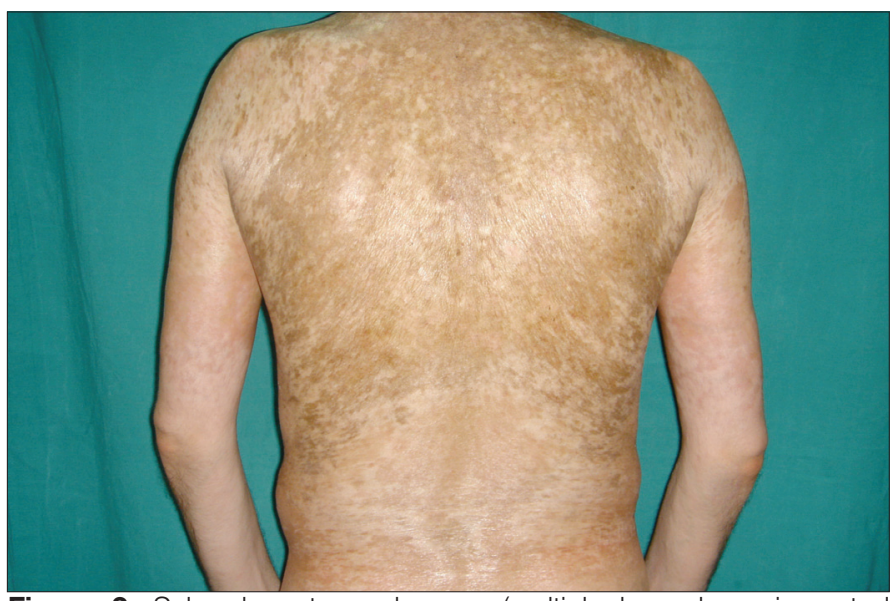

Figure 2. Sclerodermatous changes (multiple hyper-hypopigmented macules) of cGVHD presented with trunk involvement unlike acral involvement of scleroderma

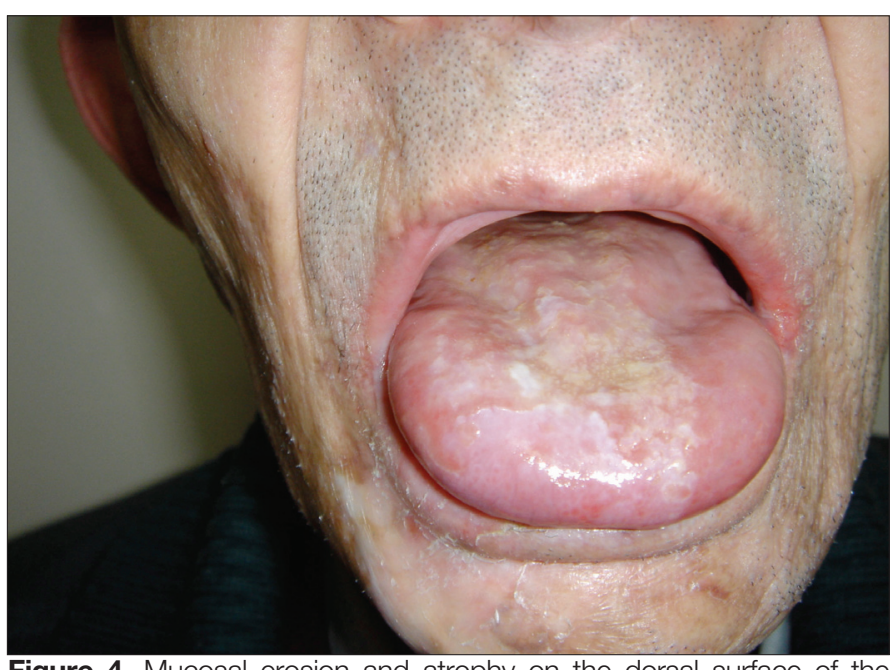

Figure 4. Mucosal erosion and atrophy on the dorsal surface of the tongue 


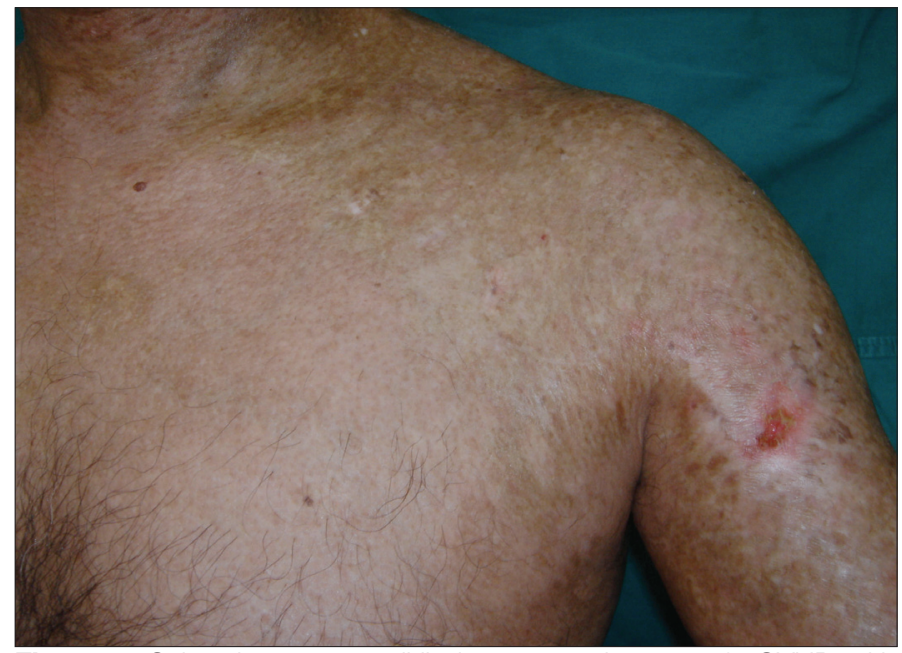

Figure 5. Sclerodermatous poikilodermatous changes of cGVHD with ulceration on the upper arm

appeared on the trunk, and distal parts of the extremities were spared (Figure 2). Joint retractions and dysphagia developed in $2(9 \%)$ patients (Figure 3). None of the patients had Raynaud phenomenon. Autoimmune markers like SCL-70, ACA, ANA, and anti-DsDNA were negative in all patients.

Thirteen patients (59\%) presented with accompanying oral mucosal involvement. Oral manifestations include reticular whitish plaques, erosions and ulcerations (Figure 4). The localizations of the lesions were buccal mucosa, tongue and gingiva.

One patient presented with lichen sclerosis-et-atrophicus and one with septal panniculitis. Other associated lesions were poikiloderma ( $n=3$ ) (Figure 5), pyogenic granuloma-like lesions $(n=1)$, bullous lesions and erosions $(n=1)$, ulcers $(n=2)$ (Figure 5), eccrine hydrocystoma $(n=1)$, acquired ichthyosis $(n=2)$, cicatricial alopecia $(n=3)$ (Figure $1)$, vitiligo $(n=2)$, sicca syndrome $(n=2)$, and salivary abnormalities $(n=5)$. There was no standard therapy. None of the patients with localized scleroderma responded to CsA therapy. Partial response was achieved in five patients with extensive sclerodermatous GVHD. Three of them received ECP, MMF and CsA combination, one received only ECP, and one was given MMF and PUVA. The number of PUVA therapies in this patient was 48 , and the total UVA dose was $135 \mathrm{~J} / \mathrm{cm}^{2}$. Duration of ECP was one year in 4 patients showing partial response and six months in 4 patients without any response. Patients treated with ECP alone or ECP plus MMF, CsA or prednisone showed statistically significant improvement compared to patients treated with other treatment regimens $(p=0.03)$. The effect of treatment appeared after three months and was maximal after seven or eight months.

Five patients died because of late transplant-related complications. All these patients had extensive disease (multi-organ involvement).

\section{Discussion}

The incidence of cGVHD is $30-50 \%$. Of these, $90-100 \%$ develops cutaneous disease. cGVHD can occur de novo, but it is seen more often following aGVHD, which is the most important risk factor for the development of CGVHD. In our study, 17 of the 22 patients (77\%) developed secondary chronic cutaneous GVHD following acute cutaneous GVHD, and in 5 patients (23\%), de novo chronic cutaneous GVHD occurred without previous aGVHD.

The mucocutaneous manifestations of cGVHD clinically resemble a wide variety of skin diseases, including lichen planus, lichenoid eruptions, sicca syndrome, morphea, scleroderma, and lichen sclerosus. Chronic cutaneous GVHD is categorized according to the type of lesions into lichenoid and sclerodermatous variants. Both types may occur in a single patient. While the literature precedent invariably associates the lichenoid manifestations of cGVHD as a part of the cutaneous manifestations of CGVHD, Magro et al. [9] suggested that the early-onset lichenoid GVHD is a unique form of aGVHD. Sclerodermatous cGVHD has the most severe skin involvement and appears late in the course of the disease [1]. It has been described in small series of patients $[1-3,5]$. In our study, the rate of sclerodermatous cGVHD among all surviving patients was similar (5.2\%) to previously reported (3.4-3.6\%) studies [2,3] but lower than in the study of Skert et al. (10.5\%) [5]. Sclerotic lesions of our patients developed after a mean of $752 \pm 647$ days (median 480, range: 3 months - 5 years). The length of time between AHSCT and the onset of sclerodermatous CGVHD has been reported within a wide range (292-2190 days, mean 730$)[1-3,5]$.

Chosidow et al. [3] found that lichenoid GVHD always preceded the sclerodermatous phase. Shulman et al. [4] suggested that patients with generalized sclerodermatous GVHD followed a biphasic course, with first a generalized erythematous or violaceous rash, and then poikiloderma with sclerotic skin. In our study, 8 of our patients (36.4\%) progressed from lichenoid to sclerodermatous lesions, 2 (9.1\%) with lichenoid and sclerodermatous phases together and 12 (55.5\%) with de novo sclerodermatous lesions.

Sclerodermatous lesions begin with indurated plaques with loss of skin markings and appendages causing pain and chronic ulceration, predisposing to generalized wasting and pyogenic infections of the skin. Sometimes subcutaneous fat and fascia are also involved, resulting in eosinophilic fasciitislike appearance. Chosidow et al. [3] reported that 4 of their 7 patients showed fibrosis in the dermis extending to the subcutaneous fat, and this association has been suggested in two recent reviews [6,7]. Penas et al. [2] suggested that septal panniculitis should be described as a histological type of scleroder- 
matous GVHD, and they found septal panniculitis in 6 (50\%) of the 12 patients with biopsy specimens available for evaluation. In the present study, we observed septal panniculitis and clinical fasciitis in only 1 patient.

In our study, the rate of lichen sclerosus-like lesions was lower (4.4\%) than in the previously reported (29-47\%) studies $[2,3]$. These lesions progressed to sclerotic areas in the late phases of the disease. Considering the retrospective nature of the present study, it is possible that those patients with early lichenoid lesions might have been missed, and the actual incidence might not have been lower than the reported studies. The presence of both lichen sclerosus-like lesions and the histological findings of septal panniculitis in the disease process suggest that the sclerosis in sclerodermatous GVHD can start and affect any level of the skin and can extend to involve the complete dermis, the subcutis, and even the fascia. Despite the fact that sclerodermatous GVHD and scleroderma have some similarities in cutaneous fibrosis, a recent study comparing the dermal microvasculature in sclerodermatous GVHD to scleroderma suggested that sclerodermatous GVHD is a suitable model for studying dermal sclerosis but may not be applicable for studying the microvascular alterations characteristic of scleroderma. Focal capillary proliferation occurs in early sclerodermatous GVHD; however, loss of endothelial markers and dermal capillaries is seen in scleroderma but not in sclerodermatous GVHD [10].

Authors have stated that leopard skin eruption-like pigmentary changes (widespread, well-demarcated, hyperpigmented macules) precede, almost constantly, the development of evident sclerosis and are very distinctive [2,11]. We observed these changes preceding the sclerotic lesions in 8 (36.4\%) patients. Poikiloderma was described as a frequent finding in the first reports of cGVHD [1]. Since then, it has been infrequently described [3]. In our study, we found poikiloderma in 3 patients (13.6\%).

Eccrine hydrocystoma has not yet been described in association with cutaneous GVHD. We found eccrine hydrocystoma in 1 patient. Here, the obstruction of the eccrine duct via sclerosis may be responsible for the development of eccrine hydrocystoma.

Sclerodermatous cGVHD can give rise to reduced range of motion and secondary effects including loss of strength, endurance and functional capabilities. In our set, joint retractions and dysphagia were found in 2 (9\%) patients. Acrosclerosis and Raynaud phenomenon, which are commonly seen in progressive scleroderma, are not frequent in sclerodermatous cGVHD [12]. None of our patients with sclerodermatous GVHD showed this phenomenon or underwent an edematous phase of systemic scleroderma. No female predominance was found. Sclerodermatous lesions tend to affect the trunk and proximal extremities while distal parts of the extremities were spared. Autoimmune markers like SCL-70 and ACA were negative. All of these data suggest that, although patients fulfill some criteria for systemic sclerosis, both diseases could have different etiopathogeneses.

In cGVHD, oral lesions are seen in approximately $80 \%$ of the patients. Oral manifestations may include xerostomia, lichen planus-like changes, reticular whitish plaques, erosions and ulcerations, and submucosal fibrosis $[6,7,13]$. Sicca syndrome of the eyes and the mouth can be seen and pyogenic granuloma formation has been reported as a rare finding $[6,7,14]$. Oral mucosa involvement was present in 13 (59\%) of our patients. The most frequent findings were mucosal ulcerations and erosions.

Survival rates for patients with cGVHD are approximately equal to rates for patients without cGVHD, regardless of treatment. Spontaneous resolution of sclerodermatous GVHD may occur. However, none of our patients showed spontaneous resolution of the lesions. cGVHD has direct influence on both mortality and morbidity. The most important causes of mortality are infections, liver dysfunction and cachexia [7]. Of the 22 patients that we studied, 5 patients died due to late transplantrelated complications.

Numerous treatments, including prednisone, azathioprine, penicillamine, CsA, methotrexate, MMF, thalidomide, clofazimine, anti-CD20 monoclonal antibody, ECP, phototherapy with bath PUVA, UVA1 or UVB, etretinate or various combinations, have been tried with varying success in sclerodermatous GVHD [2,3,5,15-22]. The best therapeutic response has been achieved with etretinate, ECP, high doses of steroid and azathioprine, and methotrexate $[2,5,15,16]$. Anti-CD20 monoclonal antibody has been found to have significant activity in the treatment of refractory sclerodermatous GVHD [22]. Imatinib mesylate 400 $\mathrm{mg} /$ day, which enables inhibition of fibroblast growth and decreased collagen production via inhibition of the transforming growth factor beta (TGFbeta) and platelet-derived growth factor (PDGF) pathways, is found to be effective especially in patients with refractory sclerodermatous cGVHD [23]. We achieved partial response in 5 patients showing extensive sclerodermatous changes. Patients treated with ECP alone or ECP plus MMF, CsA or prednisone showed statistically significant improvement compared to patients treated with other treatment regimens $(p=0.03)$. Several retrospective and prospective studies have shown the efficacy of ECP in the management of cGVHD [24]. These reports included patients who were not responsive to at least one line of therapy, in most cases steroids and CsA, and ECP had been used as adjunctive treatment. Similar to our patients, the effect of treatment 
appeared after two or three months and was generally maximal after six months. The mechanism of action of ECP in GVHD is still not entirely understood. However, several studies seem to support the hypothesis that ECP operates as an immunological response modifier [24]. In addition, ECP causes PUVA damage to $T$ cells and stimulates the differentiation of monocytes into active dendritic antigenpresenting cells. We achieved partial response in 1 patient receiving MMF and PUVA combination. Response was seen at the third month of the therapy. The number of PUVA therapies in this patient was 48 and the total UVA dose was $135 \mathrm{~J} / \mathrm{cm}^{2}$. MMF alone was not found to be effective in 2 patients.

In conclusion, sclerodermatous GVHD has a late onset and clinically may be quite disabling. Unlike scleroderma, acral involvement is seen rarely and most patients have trunk involvement with widespread, well-demarcated, hyperpigmented macules. Moderate or severe cGVHD precedes generalized sclerodermatous involvement in most patients. Although most lesions do not disappear in the course of the disease and are therapy-resistant, most patients have a good prognosis.

\section{Conflict of interest}

No author of this paper has a conflict of interest, including specific financial interests, relationships, and/or affiliations relevant to the subject matter or materials included in this manuscript.

\section{References}

1. Graham Brown RAC, Sarkany I. Scleroderma like changes due to chronic graft versus host disease. Clin Exp Dermatol 1983;8:531-8.

2. Peñas PF, Jones-Caballero $M$, Aragüés $M$, Fernández-Herrera J, Fraga J, García-Díez A. Arch Dermatol. 2002 Jul;138(7):924-34. PMID: 12071820

3. Chosidow O, Bagot M, Vernant JP, Roujeau JC, Cordonnier C, Kuentz M, Wechsler J, André C, Touraine R, Revuz J. Sclerodermatous chronic graft-versus-host disease: analysis of seven cases. J Am Acad Dermatol 1992;26:49-55.

4. Shulman HM, Sale GE, Lerner KG, Barker EA, Weiden PL, Sullivan K, Gallucci B, Thomas ED, Storb R. Chronic cutaneous graft-versus-host disease in man. Am J Pathol 1978;91:545-70.

5. Skert C, Patriarca F, Sperotto A, Cerno M, Fili C, Zaja F, Stocchi R, Geromin A, Damiani D, Fanin R. Sclerodermatous chronic graft-versus-host disease after allogeneic hematopoietic stem cell transplantation: incidence, predictors and outcome. Haematologica 2006;91:258-61.

6. Aractingi S, Chosidow O. Cutaneous graft-versus-host disease. Arch Dermatol 1998;134:602-12.

7. Johnson ML, Farmer ER. Graft versus host reactions in dermatology. J Am Acad Dermatol 1998;38:369-92.
8. Filipovich AH, Weisdorf D, Pavletic S, Socie G, Wingard JR, Lee SJ, Martin P, Chien J, Przepiorka D, Couriel D, Cowen EW, Dinndorf P, Farrell A, Hartzman R, Henslee-Downey J, Jacobsohn D, McDonald G, Mittleman B, Rizzo JD, Robinson M, Schubert M, Schultz K, Shulman H, Turner M, Vogelsang G, Flowers ME. National Institutes of Health consensus development project on criteria for clinical trials in chronic graft-versushost disease: I. Diagnosis and staging working group report. Biol Blood Marrow Transplant 2005;11:945-56.

9. Magro CM, Kerns MJ, Votava H, Vasil KE, Dyrsen ME, Morrison CD. Early-onset lichenoid graft-vs.-host disease: a unique variant of acute graft-vs.-host disease occurring in peripheral blood stem cell transplant recipients. J Cutan Pathol. 2009 Oct 15. [Epub ahead of print]

10. Fleming JN, Shulman HM, Nash RA, Johnson PY, Wight TN, Gown A, Schwartz SM. Cutaneous chronic graft-versus-host disease does not have the abnormal endothelial phenotype or vascular rarefaction characteristic of systemic sclerosis. PLoS One. 2009;4:e6203.

11. Roujeau JC, Revuz J, Touraine R. Graft versus host reactions. In: Rook A, Savin J, editors. Recent Advances in Dermatology. Vol 5. New York: Churchill Livingstone Inc, 1980: 131-57.

12. Belch J. Raynoud's phenomenon: its relevance to scleroderma. Ann Rheum Dis 1991;50:839-45.

13. Atkinson K. Chronic graft versus host disease. Bone Marrow Transplant. 1990;5:69-82.

14. Lee L, Miller PA, Maxymiw WG, Messner HA, Rotstein LE. Intraoral pyogenic granuloma after allogeneic bone marrow transplantation. Report of three cases. Oral Surg Oral Med Oral Pathol 1994;78:607-10.

15. Marcellus DC, Altomonte VL, Farmer ER, Horn TD, Freemer CS, Grant J, Vogelsang GB. Etretinate therapy for refractory sclerodermatous chronic graft-versus-host disease. Blood 1999;93:66-70.

16. Greinix HT, Volc-Platzer B, Rabitsch W, Gmeinhart B, GuevaraPineda C, Kalhs P, Krutmann J, Hönigsmann H, Ciovica M, Knobler RM. Successful use of extracorporeal photochemotherapy in the treatment of severe acute and chronic graft-versus-host disease. Blood 1998;92:3098-104.

17. Vogelsang GB, Wolff D, Altomonte V, Farmer E, Morison WL, Corio R, Horn T. Treatment of chronic graft-versus-host disease with ultraviolet irradiation and psoralen (PUVA). Bone Marrow Transplant 1996;17:1061-7.

18. Ghoreschi K, Thomas P, Penovici M, Ullmann J, Sander CA, Ledderose G, Plewig G, Kolb HJ, Röcken M. PUVA-bath photochemotherapy and isotretinoin in sclerodermatous graft-versus-host disease. Eur J Dermatol 2008;18:667-70.

19. Wetzig T, Sticherling M, Simon JC, Hegenbart U, Niederwieser D, Al-Ali HK. Medium dose long-wavelength ultraviolet A (UVA1) phototherapy for the treatment of acute and chronic graft-versus-host disease of the skin. Bone Marrow Transplant 2005;35:515-9.

20. Parker PM, Chao N, Nademanee A, O'Donnell MR, Schmidt GM, Snyder DS, Stein AS, Smith EP, Molina A, Stepan DE, 
Kashyap A, Planas I, Spielberger R, Somlo G, Margolin K, Zwingenberger K, Wilsman K, Negrin RS, Long GD, Niland JC, Blume KG, Forman SJ. Thalidomide as salvage therapy for chronic graft-versus-host disease. Blood 1995;86:3604-9.

21. Lee SJ, Wgner SA, McGarigle CJ, Bierer BE, Antin JH. Treatment of chronic graft-versus-host disease with clofazimine. Blood 1997;89:2298-302.

22. Ratanatharathorn V, Ayash L, Reynolds C, Silver S, Reddy P, Becker M, Ferrara JL, Uberti JP. Treatment of chronic graft- versus-host disease with anti-CD20 chimeric monoclonal antibody. Biol Blood Marrow Transplant 2003;9:505-11.

23. Magro L, Catteau B, Coiteux V, Bruno B, Jouet JP, Yakoub-Agha I. Efficacy of imatinib mesylate in the treatment of refractory sclerodermatous chronic GVHD. Bone Marrow Transplant 2008;42:757-60.

24. Carcagnì MR, De Aloe G, D'Ascenzo G, Rubegni P, Fimiani M. Extracorporeal photopheresis in graft-versus-host disease. J Dtsch Dermatol Ges 2008;6:451-7. 